\title{
1 Aboriginal Mission Tourism in Nineteenth Century Victoria
}

This study is concerned with the history of tourism at the Coranderrk Aboriginal station that operated near Healesville some 65km northeast of Melbourne from 1863 until its formal closure in 1924. The title of this account is 'A peep at the Blacks'. It is adapted from the title of an 1877 newspaper article written by John Stanley James, the nineteenth century travel writer, who used the pseudonym 'The Vagabond'. He was one of many journalists, researchers, and dignitaries who visited Coranderrk during its 60 years of operation to gaze at the residents. Coranderrk was one of six reserves that operated across Victoria in the second half of the nineteenth century (see Figure 1.1). Although all six reserves were places of Aboriginal incarceration, Coranderrk, because of its proximity to Melbourne, became emblematic in shaping the views of Melbourne-based policy makers (Lydon, 2002: 81). Many tropes or themes mediated the tourist gaze - the view that they were both a 'fossil race' and a 'dying race' made it imperative that they be researched before they became non-existent.

Before commencing a fine-grained study of Coranderrk it is necessary to take heed of Hall's and Tucker's (2004: 8) observation that 'Any understanding of the creation of a destination... involves placing the development of the representation of that destination within the context of the historical consumption and production of places and the means by which places have become incorporated within the global capital system'. In terms of an international culture network, Lydon (2002) has shown how images of Coranderrk Aboriginal people became scientific currency within an international network extending as far afield as England, Italy, Russia, and France. It is no surprise, therefore, that many of the international visitors to Coranderrk came from some of these countries. Consistent with this view, in order to position tourism at Coranderrk Aboriginal Station within an historical context, it is necessary to document tourist visitation at similar stations and mission sites in colonial Victoria.

\subsection{Aboriginal Mission Tourism in Colonial Victoria: an Overview}

Carolane (2008) in his study of tourism at Lake Tyers in the 1870s and 1880s has argued that this was a time when the parallel interests of experiencing the environment and viewing Aboriginal people converged into Aboriginal mission tourism. Melburnians with an interest in Victoria's coast were drawn to Lake Tyers and Ramahyuck in Gippsland whereas those with an interest in fern gullies and mountain ranges were drawn to Healesville and Coranderrk. Carolane has shown how Lake Tyers became a favourite tourist attraction and the missionary John Bulmer responded to this interest by building a guesthouse and arranging connecting transport to the newly constructed railway line to Lakes Entrance. Indeed, he has argued that missionaries such 


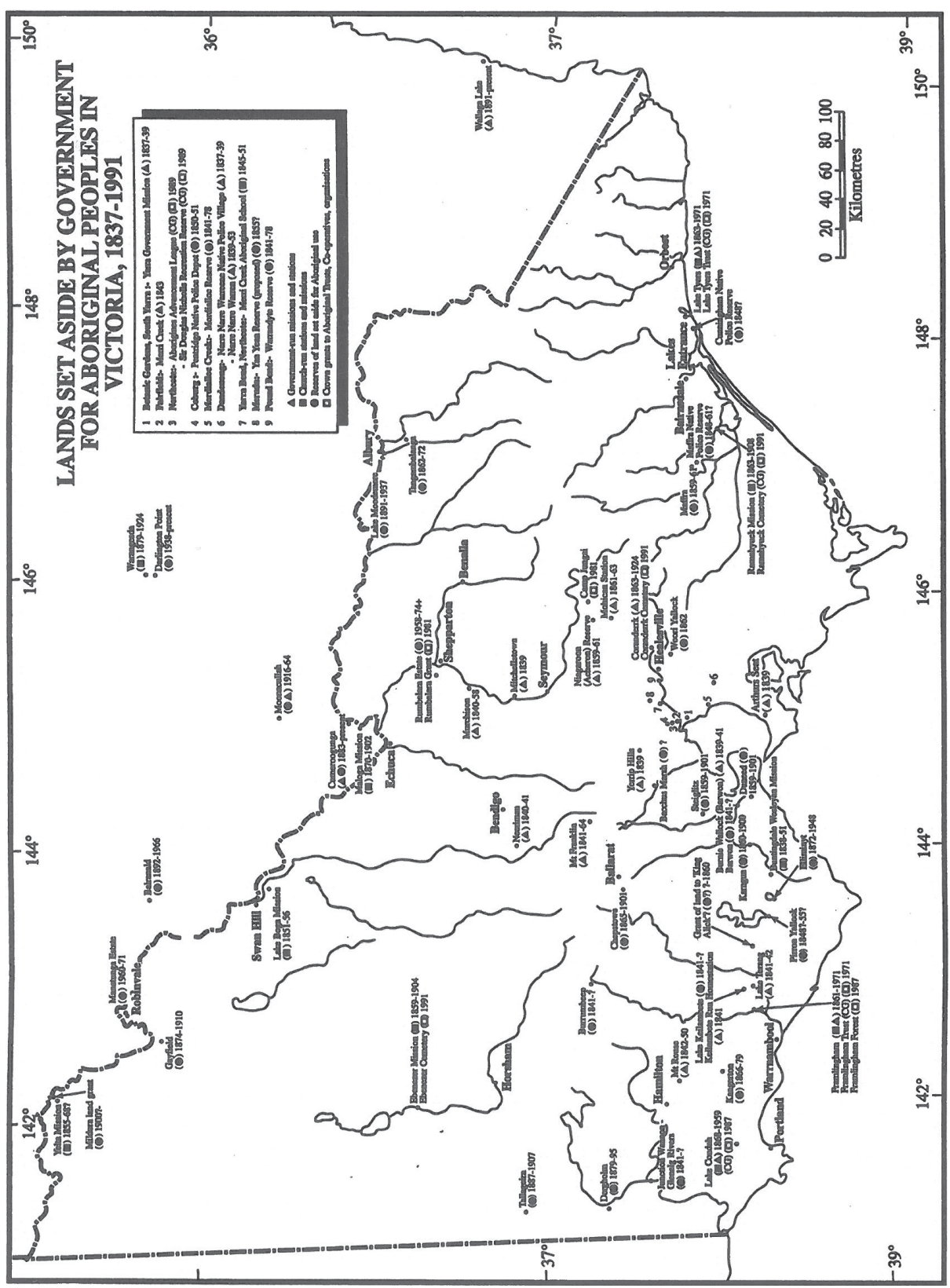

Figure 1.1: Stations and reserves set aside for Aboriginal peoples in Victoria. 
as Bulmer saw Aboriginal mission tourism as a means by which the general public could become re-engaged in the Aboriginal cause: the 'managers nervously opened their gates to visitors in the hope that it might raise public awareness, provide an opportunity to work and create some lively station activity' (Carolane, 2008: 161).

French visitor G. Verschuur (1891: 33) visited Lake Tyers Aboriginal station in late 1888 and his account is of interest because he provides full details of the guided tour given to him by the school master who was 'only too happy to point out to me everything relating to the life and education of the natives confided to the care of himself and a clergyman living near the church'. Verschuur stayed at a hotel near the Mission Station that had been built to attract travellers. At the station 'a church has been erected, and a school, and the education of the children, and even adults, is carried on in a most praiseworthy manner. As for the old people, they are left to vegetate in their huts, smoking their pipes, plunged in a half comatose state; it would only be [a] waste of time to trouble their last years of existence by instruction' (Verschuur 1891: 38). The tour of inspection began with the wooden houses of families, followed by the old people's quarters and finished with the school.

Healy (2006) has examined tourism at Lake Tyers in the 1930s when it was the only Aboriginal station operating in Victoria. When Coranderrk closed in 1924 many families were relocated to Lake Tyers. Many of the ex-Coranderrk residents brought with them a significant history of involvement in the tourism industry, something that will be demonstrated in this book, and there is little doubt that they contributed to the flourishing tourism at Lake Tyers. The visitors to Lake Tyers at this time 'numbered thousands per year' (Healy, 2006: 29) and authorities attempted to control the visitation by reducing visiting days from three to two a week despite opposition from local business operators who believed they would suffer from less tourist traffic.

Ramahyuck Aboriginal station, also in Gippsland, was another significant site where Aborigines and Europeans encountered each other: 'by and large, on occasions which were ritualised or orchestrated, as in church - where they sat separately - or when European visitors came as holiday excursionists or to attend annual picnics or some commemoration or another' (Attwood, 1989: 115). Attwood (1989) discusses the phenomena of visitors to Ramahyuck and other missions and states that 'visitors recorded the way they objectified the Aborigines in the visitors' book' (Attwood, 1989: 115). Anthony Trollope, the renowned colonial travel writer, visited Ramahyuck mission between 1871 and 1872 and wrote of his experiences (Trollope, 1967). 'I did not think that Rama Yuck [sic] was flourishing, though I was convinced by what I saw that nothing was wanting to it which philanthropy and devotion could supply' (Trollope, 1967: 499). Dr James Moorhouse, the Anglican Bishop of Melbourne, visited Ramahyuck in 1877, where he experienced his first contact with Aboriginal Australians. Visiting the Lake Tyers mission, Moorhouse was awestruck by its setting, the Aborigine's own choice at a site north of Lakes Entrance, calling it 'the fairest gem of the Gippsland Lakes' (Sturrock, 2005: 144). English tourist Walter Ryland visited Ramahyuck in December 1882 where he found seven or eight fami- 
lies of 'coloured people' living in small modern wooden houses that had been especially erected for them by the Victorian government. He noted that the 'Aboriginals in Victoria are only very few in number, and they are now rapidly decreasing in that respect. ... The few natives we saw at Rumayack [sic], cannot be commended for either the beauty of their physique, or for the expressions on their faces' (Ryland, 1886: 167). John Stanley James, a.k.a. 'The Vagabond' and 'Julian Thomas', was another travel writer of the colonial period who published papers on missions and missionary work after visiting mission sites, such as Ramahyuck and Lake Tyers (Cannon, 1969, Attwood, 1989).

Maloga Mission station on the banks of the Murray River was another tourist attraction, so much so 'that special steamer excursions came from Echuca' (Cato, 1976: 247). The Riverine Herald on 3 January 1881 stated that, 'the most popular of the excursions on New Year's Day was without doubt that of the steamer Ruby to the Aboriginal Mission Station at Maloga' (Cato, 1976: 247).

Although Giordano Nanni (2011) has argued that Victoria's Aboriginal missions and reserves quickly became isolated islands geographically surrounded by a sea of white settlements, farms and private property, this isolation requires a nuanced understanding, for it is wrong to consider that all missions and stations in Victoria were isolated to the same extent - the Coranderrk station is only 65 kilometres from the centre of Melbourne, whereas outlying stations such as Ebenezer and Lake Tyers were 400 and 350 kilometres respectively.

Coranderrk and Lake Tyers and other mission stations or reserves, were sites where mission and tourism crossed paths, however Ebenezer was not one of these stations as has been shown by Clark \& McRae (2014). The Moravian missionaries deliberately selected the Lake Hindmarsh location because of its isolation in the sparsely-settled Mallee and the enforcement of Moravian policies that forbade visitation other than by clerical and government officials, reinforced Ebenezer's isolation. Ebenezer Mission differed from other Victorian missions and stations for unlike government run missions it was administered by the Moravian Church who did not encourage public visitation. In North America, the Moravian run Native American missions, were not initially embraced by the settler communities in which they operated (Westmeier, 1997). This meant that the Moravian missions became insular and self-contained sites, which avoided contact with the outside world. The experience of traveller Richard Tester, who visited the earlier Moravian mission at Lake Boga in the early 1850 s en route to the goldfields and was refused hospitality, supports the assertion that visitors to Moravian missions were not encouraged. The missionaries stated in their encounter with Tester 'the rules of our society forbid any white men to camp within a mile of the station' (Tester, No Date). In this aspect the Moravian missionaries were strident in attempting to conceal Ebenezer from the gaze of tourists and the station's geographical isolation and the absence of any sizable settlements nearby assisted the missionaries in maintaining the mission's invisibility and limiting external visitation. 
Unlike Coranderrk and Lake Tyers, Ebenezer was never the concerted focus of tourism in the nineteenth century - the Aboriginal residents were not brought into an informal cash economy in which they made and sold Aboriginal souvenirs such as boomerangs and spears and neither were cultural performances commoditised, such as boomerang throwing and fire making (Clark \& McRae, 2014). Ebenezer did not have 'open days' in which the institution was open to the public and residents and visitors could interact. On the contrary, the Moravian missionaries did all in their power to keep the station separate from the wider secular community, even going so far as to ensure that the road to the station did not become a public thoroughfare. Jensz (2010: 187) has discussed the tension that the missionaries experienced between a general curiosity in Victoria over the work of the various mission stations, and local and international visitors keen to see their work and to see curiosities of the 'dying' race, and their need to promote their work to ensure funding continued, and that of unwanted attention that had the potential to damage the good work of the mission and subject the Aboriginal people to what they feared were debased situations. Tourism and interaction with visitors was anathema to the worldview of the Moravian missionaries the 'heathen' Aborigines 'needed to be saved from traditional lives and kept away from debauched European customs and people' (Jensz, 2010: 141) - for the Aboriginal people the cost of living on Ebenezer was the strict regulation of their lives by the missionaries who actively sought to mould them into morally upstanding replicas of themselves.

Coranderrk's proximity to Melbourne privileged its position in Victoria in terms of the focus of visitor attention - this was especially the case in the early twentieth century when Melbourne was Australia's Capital city. As this study will show in numerous instances Coranderrk was the only Aboriginal station frequented by some international visitors to Australia. Coranderrk became a primary attraction for many visiting dignitaries and it is rare to find examples of dignitaries visiting other Victorian Aboriginal stations and not visiting Coranderrk. Exceptions include Anthony Trollope (1967), who visited Ramahyuck mission between 1871 and 1872, Walter Ryland (1886), and G. Vershuur (1892).

What all six stations had in common was their temporal confinement, as explained by Nanni (2011: 11-12), 'with rules and regulations framed in an unseen matrix of temporal control. Temporal curfews sought to establish the dominance of the new colonial timetables of agriculture, pastoralism and Christianity, whilst subsuming the pre-colonial calendars, rituals and economies of Aboriginal societies'. Donnelly (2011: 65.1) has characterized the settlement of Victoria's Aboriginal people onto stations such as Coranderrk as 'a colonial project of social engineering' and she considers each station to be 'a place of refuge, and of restraint. In its more complex and elaborate objectives, it was a place where Aboriginality could be observed, documented and redefined. No gulag, it was nevertheless a place of power and conflict'.

An underlying imperative of government policy was the eventual destruction of traditional Aboriginal hunting and gathering lifestyles - Aboriginal people had 
been dispossessed of their native lands, now all that remained was to wrest them from their traditional praxis of hunting and gathering. Central to this praxis was the freedom to exploit the seasonal abundance of food resources. Thus a surface right - the ability of the land-owner to enjoy the current use of their land - was essential. European invasion necessarily meant a restriction of living space, and restraint of the right of the Aboriginal people to their own way of life and the loss of their freedom to develop in accordance with their own individuality. The transformation of the Aboriginal way of life was necessary for the transplantation of settler capitalism (Clark, 1982). The immediate micro-effects of the forced articulation of Aboriginal hunting and gathering and settler-capitalism included dispossession which amounted to proletarianization or the separation of the producer from their land (their means of production); restriction of access to food resources or an undermining or reduction of the ability of hunting and gathering to provide subsistence; a decrease in time available for traditional subsistence activities; decrease in traditional subsistence skills and knowledge; restriction of traditional seasonal movements; depopulation; generation of mixed-descent children; Aboriginal society became a dependent variable with respect to the larger forces of the settler Australian and world economy; imposition of different environmental conditions such as clothing and housing; and desecration of sacred places and an inability to perform, freely, rituals and ceremonies.

The movement of Aboriginal station residents was tightly controlled by station managers; visits between stations were permitted so long as they conformed to pastoral and agricultural calendars or timetables - 'passes' to travel were issued by managers to travel during shearing and harvest time, but not for Aboriginal hunting-time, fishing-time or corroboree-time; movement was regulated by the sensibilities of the market economy (Nanni, 2011: 15). The traditional Aboriginal mode of production was 'relegated to the secondary category of leisure and recreation', and only permitted during 'residual' time (Nanni, 2011: 17). Hunting and gathering was no longer a threat to settler-society as it had been reclassified as leisure activities. Assimilation to European ways meant conforming to orthodox temporal boundaries between work, play, and prayer. At Coranderrk, for example, in 1881, a good day's work consisted of seven hours of labour, from nine to one and from two to five, with Saturday a full holiday when the residents were free to pursue traditional activities such as hunting and gathering. The residual time after necessary 'work' and devotions had been met, came to be known as 'time off'. In these periods the Aboriginal people were free to pursue pre-colonial Aboriginal activities such as corroborees, hunting, fishing, spearmaking, tree-climbing and basket-making (Nanni, 2011: 18). Hunting and fishing and traditional games were tolerated on most Aboriginal stations, so long as they respected the temporal boundaries set aside for 'leisure' and 'recreation'. Indeed, traditional hunting and gathering was being subsumed and subordinated to settler capitalism. Of Coranderrk R. Brough Smyth, the secretary to the Board for the Protection of Aborigines reported, 'Many of the Aborigines gladly employ themselves in their 
leisure hours in fishing and the streams near Coranderrk are certainly such to tempt sportsmen to indulge in this pastime' (Victoria, 1871: 8).

The transition of hunting and gathering from activities essential to meeting the basic needs of families and communities to recreational activities to be enjoyed at leisure and play was complete when these activities became the focus of tourism consumption. Boomerang throwing was no longer an essential form of hunting - it was now a spectacle of skill that entertained tourists and visitors; Aboriginal people now had 'modern' ways of lighting fires and traditional fire-making became another skill that was commoditised.

Coranderrk and other stations, with the exception of Ebenezer, became the focus of tourists and day visitors. Indeed, it is possible to argue that tourism was a logical step in the colonization of Victoria. Yet, Healy (2006: 19) cautions against romanticizing the interest in Aboriginal tourism: 'The public's desire to witness and incorporate Aboriginal performance and material culture was based on a very restricted understanding: evidence of cross-cultural influence on Indigenous cultural practices meant that they were no longer seen as authentically Aboriginal, and such practices took place in heavily controlled environments'.

Healy's (2006) analysis of the reaction of the Board and station management to the growth of tourism interest in Lake Tyers in the 1930s reveals a fascinating tension. The Board was seeking to take advantage of Lake Tyers' relative geographical isolation at a time when the public interest in viewing Aboriginal performances and purchasing Aboriginal arts and crafts was increasing. The Board's reaction to the growing interest in tourism at Lake Tyers is paradoxical - on the one hand it believed that Aboriginal people could not withstand contact with 'civilisation' and needed to be cared for and protected as they moved inexorably towards extinction - yet while the Board sought ultimately to assimilate Aboriginal people of mixed descent into white society, society's interest in mission tourism was encouraging traditional cultural practices that were antithetical to the Board's notions of assimilation (Healy, 2006: 21, 31). In this worldview, assimilated Aboriginal people were expected to be members of the working class, employed as servants, maids, and farmhands. The Board was convinced that their civilising efforts would be compromised if they allowed visitors to Lake Tyers who encouraged the performance of traditional songs and dance and who wished to purchase 'traditional' cultural objects such as boomerangs and baskets. Instead of the commoditisation of traditional cultural activities the Board wished to see farming and housework and sewing. Cultural performances and the selling of cultural objects resisted the Board's efforts to 'civilize' Aboriginal people. The civilization process meant replacing Aboriginal corroborees with waltzes and foxtrots and picnics, and sports such as cricket and football ${ }^{1}$ replaced those of boomerang throw-

1 Of course this seems ridiculous given the argument that Australian Rules football has its origins in the Victorian Aboriginal game of Marngrook. 
ing; and knitting and sewing would replace basket making. Tourist performances and tourist art and craft, regardless of their 'authenticity', were vestiges of an uncivilised past which required erasure.

Another objection the Board had regarding mission tourism was the economic independence it offered Aboriginal people. Aboriginal people were able to exploit the presence of tourism through the sale of distinctive artefacts and staged performances (Kleinert, 2012: 91). Tourism also permitted the maintenance of cultural relationships: cultural commodity production allowed Aboriginal people to work collaboratively and draw upon their cultural heritage (Kleinert, 2012: 92). The fact remained that Aboriginal people could make more money through tourism than through farm labour. Interaction with tourists also provided the Aboriginal residents with a means to vent their opposition to Board policies and practices, or as the manager of Lake Tyers, Major Glen described it, tourism gave them the opportunity 'to get some misguided people to lend a ready ear to their imaginary grievances' (Healy, 2006: 32). As Kleinert (2012: 99), has shown at Lake Tyers, Aboriginal interaction with tourists had the potential of being subversive - tourism offered an 'alternative base for political action'.

The ability of Aboriginal people to respond successfully to the opportunities offered to them by tourism challenged the stereotypical views permeating Board policies that Aboriginal people were 'abject' and helpless and destined to die out. Denis Byrne (1996: 86) has argued that the Aboriginal response to mission tourism repudiated conventional views that Aboriginal people were unable to adapt to change. At Lake Tyers the manager responded by reducing the number of visiting days from three to two per week. The local non-Aboriginal community voiced their opposition to this change, arguing that the reduced tourism traffic threatened their businesses. The Lake Tyers manager, Major Glen, reported on 6 February 1937 that between 26 December 1936 and 16 January 1937, 'by actual count, 2,223 visitors invaded the station, and since the latter date there were approximately another 400’ (Healy, 2006: 33).

Healy's assessment is that her study of tourism at Lake Tyers Aboriginal station in the 1930s reveals that Aboriginal people were not simply passive victims of the whims and fancies of the Board for the Protection of Aborigines. Lake Tyers management believed there was a correlation between Aboriginal resistance and insolence and levels of tourist visitation. The manager, Major Glen's report on the two-month period ending 31 January 1933 noted that 'visitors are numerous this season, which partly accounts for the hostile attitude recently displayed by our charges' (Healy, 2006: 32).

The actions of the residents of Lake Tyers demonstrate that there was cultural exchange occurring in both directions ... they made choices about how they interacted with the white population. The residents could also resist and undermine the repressive policies of the Board. Regardless of the BPA's efforts, Aboriginal residents of Lake Tyers continued to have contact with the rest of the world, and to play a small but significant part in shaping Australia's national culture and identity (Healy, 2006: 34). 
Carolane's (2008: 161) analysis of Healy's study is that it revealed a public that was expecting to be entertained by exotic and preserved ancient peoples, viewed in a zoolike fashion. Focussing on Lake Tyers, Carolane investigates the inception of tourism at the station during the late 1870s-80s under the leadership of Church of England missionary John Bulmer. He characterises the 1870 s as a period of scepticism towards the likely success of Aboriginal mission and tourism confronted this scepticism by offering a way for Aboriginal missions to re-engage with an increasingly apathetic public.

In Lake Tyers, mission tourism became a dominating feature of station life. Tourists came to soak up the natural beauty of the bush landscape and view the Aborigines. While on the station, residents were not seen as a threat because they were in a controlled environment under the influence of the missionary. In the case of Lake Tyers, Bulmer adapted to this new era of mission tourism by becoming a tour guide. Tourism raised the station's profile, an appealing prospect considering the declining financial support. ... Apart from the constant objectification and patronising encounters with the Aborigines by the tourists, Bulmer was compelled to devote much of his time to catering for the visitors. The daily interruption of staring crowds reinforced a paternalistic and shallow sympathy towards the residents at Lake Tyers (Carolane, 2008: 162).

Goodall (1996) has noted that reserves such as Coranderrk are often regarded as 'concentration' camps and places of repression and segregation by many Aboriginal people. This latter view resonates with van Toorn's (2006: 17) analysis that Aboriginal reserves and missions were institutions 'where ideological apparatuses such as school and church were combined with physically coercive state apparatuses such as gaol, children's dormitory, and forced labour camp. ... Oppressive as they were, the reserves were viewed by many Aborigines as their only place of asylum and/or their only option for staying on or near their country'.

Van Toorn (2006: 27) in an analysis of the Lake Condah Mission station in southwestern Victoria has argued that 'there is less evidence of hegemonic control than of realised or threatened coercion, less evidence of spontaneous consent to oppression than of feigned consent to avoid punishment'. (Emphasis in original). Aboriginal resistance to the control of station managers and missionaries carried the threat that '[i]ndividuals who complained could be exiled to distant reserves far from kin and homeland. A sustained chorus of Aboriginal complaints could lead to closure of the reserve altogether, and thus the loss of the whole group's traditional or adopted home' (van Toorn, 2006: 17). Sometimes, however, Aboriginal people 'dropped all pretence of gratitude, obedience, and equanimity, and protested against actions of individual reserve managers and/or oppressive policies formulated by the Protection Board' (van Toorn, 2006: 18). There are numerous instances of these ruptures at Coranderrk - especially in the years between John Green's resignation and the appointment of Joseph Shaw - Diane Barwick (1998) has thoroughly researched this period which she has dubbed 'rebellion at Coranderrk'.

Jane Lydon has made a detailed study of Coranderrk, although her concern is primarily with the ways in which the Coranderrk residents influenced and used the 
ways that they were photographed for their own political ends (Jeffery, 2006: 128). She challenges the paradigm that Aboriginal people in the nineteenth century were helpless subjects exploited by photographers for academic or commercial interests. Lydon's central argument is that the images taken at Coranderrk 'reflect indigenous objectives and values, and configure an intimate form of cross-cultural communication' (Lydon, 2005: xiv). The Coranderrk residents became adept at manipulating photographic representations in their own causes.

One of the threads that will run through this study is that similar to their interplay with photography, the Aboriginal residents of Coranderrk took advantage of the opportunities offered to them by tourism, to achieve a range of goals including access to money which gave them some financial independence; and an opportunity to demonstrate that their Aboriginality was vibrant; and, when it was warranted, a means with which to advocate for their political causes and interests. In agreement with Kleinert (2012: 86), tourism is a complex and contested space - in which for Aboriginal people at Coranderrk it came to represent a practical way of 'keeping up culture' and for the many visitors it was the means to gaze upon and interact with a 'primitive' other.

Markus (1977: 177) has characterised Coranderrk as a spectacular success that revealed a rapid 'crumpling' of Aboriginal society and an equally rapid adaptation of Aborigines surviving the act of dispossession'. At Coranderrk, 'Aborigines cleared the land, fenced the property, cut a channel for irrigation and planted a wide range of crops. Visitors to the reserves in the 1870s and 1880s found the 'residents' dress, homes, and furnishings equal to those of English working men and superior to those of many selectors' (Markus, 1977: 177).

\subsection{Methodology and Sources}

This qualitative research into the history of tourism at Coranderrk Aboriginal station will employ a narrative form using a chronological approach to the evolution of the station. It will explore events as they unfold and provide a biography of key individuals where necessary. It will also explore a number of key 'themes' and perspectives. It will employ the method of 'thick description' which Norman Denzin (1989: 83) has described as narrative that 'presents detail, context, emotion, and the webs of social relationships. ... The voices, feelings, actions, and meanings of interacting individuals are heard'. For Ponteretto (2006: 542-3) ‘thick description' has numerous essential components: a description and interpretation of social actions within the context in which the social actions took place; a capture of the thoughts, emotions and web of social interaction among observed participants in their operating context; assigning motivations and intentions for the said social interactions; the reader experiences a sense of verisimilitude or likelihood as they read the researcher's account; and finally it promotes 'thick interpretation' of these actions which lead to 'thick meaning' of the 
findings. Fels (2011: 397) has explained thick description as 'giving the reader as much detail and context as possible, so that the reader is offered the possibility of knowing nearly as much as the researcher'.

Coranderrk as a tourist destination has left a rich archive - there are many accounts from tourists and visitors and a vast photographic archive - Lydon (2002: 78) suggests 3,000 images were taken - and an equally significant number of postcards and a small number of stereoscopes. This reveals the station's emblematic status as a 'showplace'. Photographs of Coranderrk 'were widely circulated and more abundant than images from most Aboriginal communities in Australia, so they are a valuable source for considering shifts in colonial photographic practice, and ways of seeing Aboriginal people and various relations and identities over time' (Kratz, 2008: 3043).

Published in this book are unique photographs taken by tourists and Coranderrk postcards with written comments from visitors of their impression of the station and its Aboriginal residents. Added to these visual texts are records generated by Coranderrk officials and the diaries of two officials - Christian Ogilvie and Natalie Robarts - and numerous contributions from three children of two of the superintendents of the station. A third corpus of material is the published and unpublished English and non-English accounts from the many visitors and tourists to Coranderrk - some translated and published here for the first time.

Much of the historiography of Coranderrk has been about Coranderrk's first superintendent John Green and the rebellion of the Coranderrk residents following his resignation in 1874 that led to two major enquiries in 1877 and 1881 and many changes of management until stability returned with the appointment of Joseph Shaw in 1886. This study is not about Green or the rebellion - though where Green is relevant to this study is the extent to which he encouraged the Aboriginal community to take control of its own development and the place of tourism in this co-existence and self-determination (Gunson, 2007: 31). The seeds of a developing self-determination were first sown at Acheron and Mohican, the Upper Yarra stations which preceded Coranderrk, where Aboriginal women's basket making is evidence of retention of cultural identity in a new colonial setting (McBryde in Gunson, 2007: 31). However, the rebellion is relevant to the degree that it shaped and influenced tourism at Coranderrk. A thread running through this study will be that the Aboriginal residents of Coranderrk appropriated tourism at many levels - as a means of cultural retention and identity - through performances of traditional skills such as basket making, fire making, tree climbing, and spear and boomerang throwing and through the sale of artefacts; as a means of livelihood - the sale of tourist objects supplementing their rations and what food their hunting and fishing could provide; and as a means of agency - interacting with tourists and visitors through which they could assert their self-determination by advocating their rights and interests. 


\subsection{Histories of Coranderrk}

This book is not a comprehensive history of the Coranderrk Aboriginal station. Although Barwick's (1998) and Lydon's (2005) books are seminal publications about Coranderrk they are about a particular episode (Barwick) or a particular theme (Lydon). Diane Barwick's Rebellion at Coranderrk, published posthumously in 1998, is primarily concerned with the period between 1874 and 1886 when Aboriginal families 'fought to keep their land and how they finally lost it'. Jane Lydon's Eye Contact, published in 2005, investigated the role of photography in the cross-cultural engagement that took place at Coranderrk. Lydon focuses principally on the photography of Walter, Kruger, and Caire and to a lesser extent Giglioli, Charnay, and Fysh.

Giordano Nanni and Andrea James (2013) Coranderrk: We Will Show the Country is concerned with the 1881 Parliamentary Inquiry into Coranderrk; and a recent book published by the author (Clark, 2014), The Last Matron of Coranderrk, is a collection of primary texts including, in full, for the first time, the fourth part of matron Natalie Robarts's diary of the final years of Coranderrk Aboriginal station that covers the years 1917 to 1923. Ethel Shaw, the daughter of Joseph Shaw (teacher and manager of Coranderrk), published a history of Coranderrk in a three-part series that appeared in the Healesville Guardian in 1943 and in 1949 published a larger booklet for private circulation. Ethel Shaw lived at Coranderrk for some 23 years. Colin MacDonald (1963) is another Shaw descendant who has published a short history of Coranderrk - he 'spent many happy childhood holidays there' (MacDonald, 1963: 105) - although this is largely derived from Ethel Shaw's 1949 publication. Aldo Massola (1975) has published a brief history of Coranderrk in which he published extracts from the works of select visitors to Coranderrk - such as Giglioli and Charnay which he translated and published in English for the first time. In this present work these non-English accounts of visits to Coranderrk are translated and published in full and some interesting discrepancies are found between Massola's (1975) translations and the ones published here.

\subsection{Studies of Tourism at Coranderrk}

Lydon's (2005) study of photography at Coranderrk has shown how the station became a 'showplace' of Aboriginal culture, and how it was visited by many local and international visitors many of whom have left a photographic record who were keen to participate in what they thought was 'the work of salvage, collecting information and taking photographs to serve as scientific data' (Lydon, 2005: xx).

Lydon's central argument is that 'while Aboriginal people were entangled in western cultures of imaging and scopic regimes that objectify, reify and distance, they absorbed and understood those practices, not as passive subjects, but as active, visually and politically astute agents in cross-cultural practices of imaging and image 
consumption. These in turn were grounded in cultural concepts of the image, rooted in ideas of kin and land expressed through performance, song and art - far removed from western perspectivalism and the disciplinary gaze - and in the absorption and mimicry of colonial practices' (Edwards, 2007: 78). Her reading of the photographic archive of Coranderrk is that images reveal not only the colonial gaze but also 'an Indigenous insertion in the photographic exchange' (De Lorenzo, 2006: 292). When Aboriginal subjects avert their gaze, Lydon argues that they are adhering to traditional practices of avoiding direct eye contact which was often considered offensive. By avoiding eye contact, Lydon argues, the Aboriginal participant retained some authority within the making of the image. Thus gaze aversion was a form of cultural subversion (see Lydon, 2005: 8-9).

The official photographic archive records the way in which visitors were shown a place marked by "discipline" and "souvenirs" of cultural difference. Where images of hybridity were concocted by the photographer in what Lydon calls "a theatre of the grotesque" - royal appellations for just about anybody in a last-ditch attempt to sound respectful to whoever had survived the degrading experience of colonialism; trousers were worn under possum skin cloaks; boomerang throwing amidst cricket games - opportunities abounded for what another historian has called "the hegemony of laughter". Against the overwhelming odds, Lydon finds some means of recognizing in these images a form of counter attack, whereby "performing traditional culture would become a source of status and income": some people demanded money for being photographed while others turned artifacts, made for demonstration and display, into saleable products (De Lorenzo, 2006: 295).

Lydon (2005: 22) has observed 'Coranderrk was unusual in its level of contact with European society: the station's proximity to white settlement saw a constant flow of visitors toward it ... the problem of maintaining the residents' seclusion became a constant theme'. Lydon (2005: 22f) further notes that once the Board had 'enforced its assimilation policy in the mid-1880s, the Board allowed the station to become a showplace, open to visitors, and as tourism out of Melbourne developed, Coranderrk became a must-see site on an itinerary that extended northeast into the Dandenongs'.

Coranderrk as a choice of study is a rich one - as acknowledged by Kratz (2008: 3043) 'Coranderrk figured in multiple arenas as the colony developed, including politics and policies relating to land and Aboriginal stations, colonial science, displays for international exhibitions, and colonial social life and entertainment as Coranderrk became a popular tourist destination'. The residents of Coranderrk, as argued by Kleinert (2006: 76), were adept at exploiting their proximity to Melbourne to assert their ownership of Coranderrk land. 'Staging Aboriginality through public performances - even within the constraints imposed by assimilation policies - fulfilled an important role. Bringing Indigenous performers and audience participants together created a context for the possible renegotiation of identities'. 


\subsection{Coranderrk Aboriginal Station - a Brief History}

In late 1849 the Port Phillip Aboriginal Protectorate was dismantled following the recommendations from the New South Wales Legislative Council Select Committee appointed in June 1849 to assess the success or failure of the Protectorate system. Although William Thomas, the assistant protector responsible for the Melbourne or Western Port Protectorate District, was retained and given the title of 'Guardian of Aborigines', he was primarily responsible for the counties of Bourke, Mornington, and Evelyn, and he concentrated his efforts on Aboriginal people living in or visiting the environs of Melbourne.

The abolition of the Protectorate heralded a decade of laissez faire policy and neglect of Aboriginal people in Victoria. For Aboriginal people in Victoria, the decade of the 1850s, can be characterised as one of continued depopulation due to venereal and respiratory diseases, sub-standard nutrition, and falling fertility rates. Traditional socio-political structures were collapsing, and depleted family units were camped either on European stations, where they were receiving seasonal employment, or they were camped on the fringes of small townships. Throughout this decade Aboriginal people received minimal government assistance. In 1858 a Select Committee of the Legislative Council of Victoria was appointed to enquire into the present condition of the Aborigines and the best means of alleviating their absolute wants. The Select Committee recommended that reserves be formed for the various tribes on their traditional hunting ranges where they would be able to combine agriculture and the grazing of livestock.

In June 1860 the Victorian Government established a Central Board 'to watch over the interests of the Aborigines'. The board operated two systems of organization: a reserve system and a system of Local Guardians, who functioned as Honorary Correspondents to the Central Board, and who distributed items of foodstuffs and clothing and other items to the Aborigines in their neighbourhoods, at locations that were considered 'depots'. In its first annual report the Central Board (Victoria, 1861), announced a nine-point plan that it would attempt to introduce:

1. That it is the bounden duty of the people who have taken possession of their country to protect them as far as possible, and to a certain extent to maintain them. We occupy for pastoral and for other purposes nearly all the land in the colony, and that which we do not occupy is the least fitted for the black population. Under these circumstances it is necessary that permanent reserves should be made for the blacks whenever their numbers are such as to require a tract of country yielding food.

2. That they should be confined as closely as possible to those reserves; and, for their better management and control, that the Act relating to the Aborigines should be amended giving to Your Excellency full power to order as to their residence and maintenance; and to order, also, as to the disposal of orphan and deserted children. 
3. That other than educated blacks in the employment of settlers should be prohibited from visiting towns and gold fields.

4. That rations and clothing should be distributed to them when necessary.

5. That medical aid should be afforded in certain cases.

6. That habits of industry should be inculcated and encouraged by forming Aboriginal settlements in the localities to which the blacks chiefly resort where some could be taught farming and the management of sheep and cattle; whilst others might be encouraged to support themselves by hunting and fishing, to build houses and to provide clothing.

7. That severe measures of repression should be urged against the sale of spirituous liquors to the blacks.

8. That missions should be encouraged, and the population of each reserve, where practicable, placed under the care of missionaries, subject to the inspection of the honorary correspondents and the inspectors appointed by the Board.

9. That a superintendent should be appointed whose duty would be to visit each station at least once in every year, examine into the condition of the blacks and report thereon, as well as report as to the distribution of stores by the honorary correspondents and the missionaries (Victoria, 1861: 11).

It was the Central Board's plan that after supplying the honorary correspondents and the superintendents of the various stations with food and clothing for the Aborigines, that Thomas, the Guardian of Aborigines, would visit each station and depot and make a careful report on the numbers and physical and moral condition of the several tribes across the state. Thomas's deteriorating health, however, made him unfit for the arduous duty of inspection, and they looked for a replacement. After much enquiry in August 1861 the Board appointed 31 year old Scotsman John Green, who had arrived in Melbourne in 1857, 'who appears to be fully qualified by experience and character to examine and report as to the condition of the blacks, and he is now engaged in visiting the several depots and stations throughout the Colony. By such means the Board will obtain an almost perfect census of the Aboriginal population, and careful returns will be made of the distribution of all stores supplied for their want. He will also report particularly as to the propriety of affording medical aid, and whether it is possible, regard being had to the habits of the blacks, to mitigate to any great extent, the frightful disorders which destroy yearly so great numbers of the Aboriginal population' (Victoria, 1861: 6). Green's title was 'General Inspector'. According to Green, he accepted the position on the condition that he was allowed to collect orphaned children on his tours and 'make a home for them' (Barwick, 1998: 65). ${ }^{2}$

2 Green was confirmed in the role in 1863. 
A brief roll call of those who served as managers or superintendents at Coranderrk and its antecedent stations at Acheron and Mohican reveals a constant procession of change since 1859. The only major periods of stability were those of John Green (1862-1876); Joseph Shaw (1886-1908); and Charles Robarts (1909-1924). (Appendix 8.1 presents a detailed biographical history of each manager and their immediate families.)

The first superintendent appointed in the Upper Yarra district was 20 year old Irish-born Robert Onslow Bellerophon Hickson and his new wife Emily Villeneufve Watton who were hired by William Thomas as superintendent and teacher, respectively, at the Acheron Reserve, some $114 \mathrm{~km}$ from Melbourne, on the Acheron River, on 30 March 1859, at 10 shillings a day. ${ }^{3}$ William Thomas's journal reveals that Thomas formally recommended Robert Hickson to have charge of the 'Nyageron' station (Stephens, 2014 v. 3: 201). When Thomas advised the 'Goulburn Blacks' that Hickson would have charge of the station he noted 'they are pleased say he is a good man they know him a long time' (Stephens, 2014 v. 4: 203). Thomas later confirmed 'Hickson has been familiar with the Blacks now intending to locate for the last 5 or six years and used to agriculture from his youth, as also has Mrs Hickson, \& for years had Blacks under her Charge teaching children to needlework, wash \& read at Mt. Rouse Aboriginal Station being the daughter of the late Amiable Protector there Dr Wotton [sic]. These are strongly recommended by W.L. Ker Esq. J.P, [...] Aitkin Esqr. JP, Snodgrass JP, all of the Upper Plenty, ${ }^{4}$ the blacks too are anxious that Mr R. Hickson should instruct them' (Stephens, 2014 v. 3: 212).

The Acheron Aboriginal station was south of the junction of the Acheron and Little rivers and formed part of the Niagaroon (Whranregarwen) and Taggerty pastoral runs.

Basket making was evidently one activity under the superintendence of Robert and Emily Hickson as Thomas noted in December 1859 that the Governor 'was pleased with Lubras baskets, \& talkd of coming to see them, Beg him to state all to Blk Lubras' (Stephens, 2014 v. 3: 242). Barwick (1998: 41) confirms that by August 1859 the women were producing and selling baskets to purchase food and tools.

In June 1860 the newly-created Central Board appointed to watch over the interests of the aborigines held their first meeting. One of the most pressing matters they had to deal with concerned the management of the Mohican station on the Acheron River:

3 They were still receiving this level of payment in February 1860 (see The Argus, 22/2/1860).

4 According to Billis's and Kenyon's (1974) register of pastoral pioneers and stations, W.L. Ker was at 'Mount Pleasant', 25,600 acres adjoining Alexandra and 'Killingworth' or 'Cheviot Hills', 50,000 acres adjoining Yea; J.C. Aitken was at 'Acheron', 24,000 acres on the Acheron River; and Peter Snodgrass was at 'Doogallook', 26,800 acres near Yea. 
The Acheron Station appeared to be under the charge of trustees, ${ }^{5}$ who were also honorary correspondents of the board, and to these gentlemen the care of it was committed. On their recommendation the old station was abandoned, and at the first meeting of the board they were placed in possession of the papers relating to the purchase of Jones Station, in the vicinity. Having no personal knowledge of the localities, und under the impression that the removal would be beneficial to the blacks, the board, on consideration of the evidence submitted to them, advised the Government to purchase Jones's Station (an arrangement all but completed when first brought under their notice), and Mr Hickson, the superintendent, took possession of it accordingly. The board regret to have to state that the change has not proved beneficial. Whether due to improper management or to the unsuitableness of the site, or both combined, it is certain that the blacks have almost ceased to frequent the new reserve. They are said to complain of the coldness of the climate, and some old settlers inform the board that no worse situation for an aboriginal establishment could be chosen. The old station was selected by the Goulburn Aborigines, and they seemed to like it extremely, and as many as ninety blacks were congregated there at first. Now, at the new station, there are seldom more than twenty five or thirty, and these are dissatisfied and careless of its success. This extraordinary change called for inquiry, the more especially as one of the trustees, Mr Snodgrass, M.L.A., had expressed himself as dissatisfied with the management of the station generally. Mr Hickson, the superintendent, was accordingly directed to appear before the board, and from his statements, and those of the gentleman in the neighbourhood, they have come to the conclusion that the new station must be abandoned. It must be remembered that it was selected in the first instance by those who ought to have been well aware of its suitableness, otherwise, for aboriginal purposes, and the board only consented to ratify the engagement for the purchase on their representations ... (The Argus, 15/10/1861).

In August/September 1860 the station moved from Acheron because of settler opposition to a new site 'Mohican Station' some four miles lower down the river. ${ }^{6}$ This land was in poor condition and the relocation was not popular with the Aboriginal residents.

In March 1861, the Board rejected trustee Snodgrass's demand that Hickson be dismissed because his 'character was an annoyance'. Once his demand had been rejected, Snodgrass himself resigned and Hickson thereafter reported directly to the Board's secretary. In April 1861 the Victorian Legislative Assembly approved a budget of $£ 200$ for the teacher and matron at the Acheron Station (The Age, 26/4/1861).

On 1 May 1861, the Legislative Assembly approved a miscellaneous request to provide compensation to Stephen Jones for loss of sheep and damage to the Mohican Station, on the Acheron River, by aborigines, of $€ 1000$ (The Age, 2/5/1861).

In terms of additional estimates for the year 1861, the Legislative Assembly on 17 May 1861, approved the following matters:

5 The trustees were Peter Snodgrass, John Maxwell, John C. Aitken, and Donald Mackenzie. 6 In an interesting twist, the Niagaroon pastoral station's association with the Hickson/Watton family returned in the latter part of the nineteenth century when John Mayne Conolly (1824-1891), who married Emily Watton's sister Mary Sophia Watton (1829?-1920) in 1857, became a licensee of Niagaroon station (The Argus, 7/7/1920). 


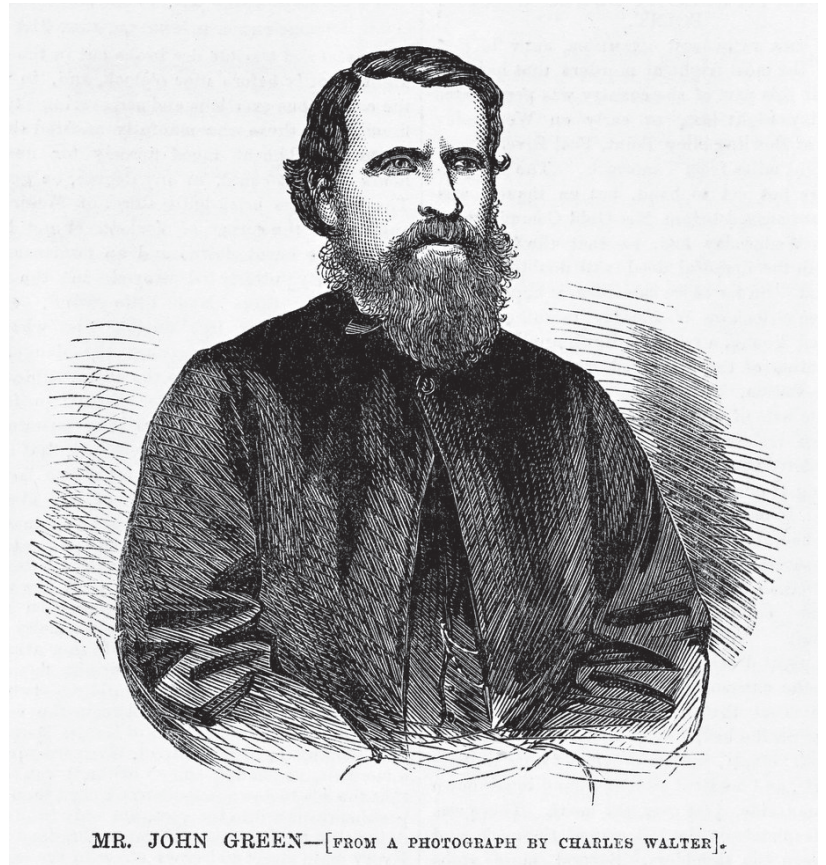

Figure 1.2: Mr John Green, The Australian News for Home Readers, 25/8/1865; State Library of Victoria Pictures Collection, Accession No. IAN25/08/65/13.

compensation to the successful tenderer for the erection of a hut on the proposed aboriginal reserve on the Acheron River, the order for the erection of the building having been rescinded in consequence of the purchase (subsequent to the acceptance of the tender) of some buildings for the use of the aborigines on the Mohican station, £25 (The Age, 18/5/1861).

In October 1861, John Green (see Figure 1.2) reported on the state of the Mohican station. He noted that he had spent a week at the station and considered it was in 'a very unsatisfactory condition', with only 16 people presently on the station; the scholars, though clean, were poorly taught, and the Hicksons were neither popular nor suitable: 'they do not like Mr \& Mrs Hickson, they say that they are no good for black fellow and black lubra, Hickson too proud'. Although 'very faithful', Green considered the Hicksons 'have not a tack for the blacks', and 'it would be wisdom' to replace them (Stephens, 2014 v. 3: 360). He noted that the five women on the station made dresses and baskets which he proposed could be sold.

Evidently there is more to the demise of the Hicksons for in March 1862 Thomas received a visit from a 'Gentleman from Upper Goulbourne come to my house, and gave an Acct of ... how contemptuously the Blks used Mr Hickson after Mr Greens arrival' (Stephens, 2014 v. 3: 375). The situation had obviously deteriorated from April 
1860 when the Brataualung Aboriginal man Boon-bul-wa aka Tarra Bobby - who belonged to the Warrigal Creek and Tarra River in Gippsland - first saw the Acheron Reserve (Stephens, 2014 v. 3: 265). There he found Aboriginal people working the land 'like white man' under the guidance of Robert Hickson. Attwood (1987: 47) observes he was most excited by what he saw and on his return to Melbourne gave William Thomas 'a glowing account of blacks working hard, making paddocks \&c. \&c.' telling him 'blackfellows Gippsland by and by like that'.

John Green first appears in William Thomas's journal on 31 October 1860 when Thomas records 'Mr Green Missiony brings 2 Blks Tommy Gippsland \& Munnering Yarra to Melbn Hospital', and the second entry on the following day, Thomas refers to him as Rev'd Mr Green calls on me, \& gives me some Acct of Blks \& Children at the Upper Yarra' (Stephens, 2014 v. 3: 286).

From late 1861 Green took over the running of the station and in early January 1862 the Board asked Hickson to resign and offered three months' notice, however, Robert and Emily Hickson refused their offer and formally resigned in January 1862, 'angry at being told he was unsuitable and at the "impertinence" of the Taunguruong who would not obey him once Green told them he no longer had authority' (Barwick, 1998: 61).

Green took over, formally, in February 1862. In March 1862 the station moved a little distance to the north, but still remained within the boundaries of the Mohican pastoral run (Sinnott, 2003). At the same time Green permanently relocated his family to the new site. This site was abandoned because it was deemed too cold, and in 1863 the Coranderrk station was established on Coranderrk (Badger) Creek, south of Healesville. Coranderrk is the Woiwurrung word for the Victorian Christmas Bush, a species of Mint Bush (Prostanthera lasianthos). According to Massola (1975: 14), the Daungwurrung name for this plant was Geringdah. The dry straight stems of the bush were used as firedrills, spun between the hands on a base of grass-tree stem to create fire by friction (Gott, 2010).

The reserve of 4000 acres at Coranderrk was gazetted in June 1863. Ethel Shaw, the daughter of Joseph Shaw, station manager from 1886 until 1908, has reflected on the suitability of the site:

The site chosen for the home of the Aborigines was ideal; it was on high ground which sloped gently down to the Badger Creek, a lovely, quick-flowing stream, purling merrily along on its way to join the Yarra River, about a mile distant. Its banks were lined with wattles, ferns, and shrubs, festooned with starry white clematis and purple sarsaparilla. The Christmas shrub (Prostanthera Lasianthos) grew luxuriantly everywhere, the beautiful sprays of delicate mauve and creamy bell-shaped flowers delighted the eye. The Yarra tribe knew it by the name of Coranderrk, and so the Mission was named after it. The reserve contained 4000 acres of well-timbered, undulating country, ranging from Mt. Riddell and Mt. Donnabewong to the River Yarra, with its rich, fertile flats. There was an abundance of wild game on the reserve - kangaroos, wallabies, koalas, possums, wombats, bandicoots, and small kangaroo rats; all were delectable articles of diet to the Aborigine. Soon land was cleared for cultivation, and bark cottages erected for those who would live in them; many, however, preferred their mia-mias (Shaw, 1949: 13). 
In 1869 the Victorian Parliament passed the Act to provide for the Protection and Maintenance of the Aboriginal Natives of Victoria which gave the Central Board for the Protection of Aborigines legal power over the lives and finances of Victoria's Aboriginal people. The 1869 Act defined an Aboriginal person to be 'Every Aboriginal native of Australia and every Aboriginal half-caste or child habitually associating and living with Aboriginals'. In the 1870s the Board would begin to develop a strategy to rid the Victorian government of the financial burden of supporting the Aboriginal people of Victoria. The plan involved removing people of mixed descent from the six Aboriginal stations and reserves in Victoria and obliging them to 'merge' with the general population. Those of full descent would be allowed to remain on stations and reserves which would be gradually merged until their eventual demise. Thus interracial relationships or genetic absorption would ultimately lead to the demise of the entire Aboriginal population and see the complete cessation of any financial burden on the state (Ellinghouse, 2001). This worldview was ultimately responsible for the $1886 \mathrm{Act}$ (see below).

In 1874 Green and the Board fell out when R. Brough Smyth, the secretary of the Board attempted to sell part of the Coranderrk reserve. Smyth wished to relocate the Coranderrk residents to the Murray River. John Green resigned as manager of Coranderrk in September 1874, though he retained his role of general inspector until October 1875.

In 1875 the Board for the Protection of Aborigines underwent a major shakeup: three new members - all close friends and each with long pastoral histories in Victoria - joined the Board - Chief Inspector of Stock Edward Micklethwaite Curr, parliamentarian Frederick Race Godfrey, and the director of the Zoological Gardens Albert Le Soüef. All three were sympathetic to the views of R. Brough Smyth, who had been instrumental in the campaign against former Coranderrk manager, John Green. 'All three had strong personal connections dating back to their time as pastoralists in the 1840s' (Furphy, 2013a: 130). Barwick (1998: 77) has characterised them as three old pastoralists who knew nothing of Kulin history or social organisation but prided themselves on their knowledge of 'the blacks'. However, Barwick's view is somewhat extreme and does not withstand scrutiny - certainly Curr's primary experience was with the Yorta Yorta to the north of the eastern Kulin peoples, but he had had considerable experience with the Ngurai-illum wurrung people, the northern-most people of the eastern Kulin confederation. Godfrey had occupied land that bordered two western Kulin languages - Barababaraba and Djadjawurrung indeed some of the Djadjawurrung were settled at Coranderrk. Finally, Le Soüef had been associated with the Daungwurrung and Ngurai-illam wurrung since his father became assistant protector of the Goulburn District of the Aboriginal Protectorate in 1841 and after his father's dismissal in 1843 he had pursued pastoral interests in the Goulburn district.

On 4 August 1875, Curr, Godfrey, and Le Soüef formed a subcommittee to examine the future management of Coranderrk and visited the station on 8 August. On 
25 August 1875, the Aboriginal Board resolved to employ for two months an experienced pastoral station manager to inspect all six stations under the Board's control in company with Board member E.M. Curr. They chose Christian Splidt Ogilvie a 55-year old Englishman who had been in Victoria since 1839. Barwick (1998: 113) is correct in her assessment that Ogilvie was 'one of their own kind' - he was a close personal friend of both Curr and Le Soüef. Ogilvie had been a stock inspector in Victoria and had once been in business with Le Soüef. The day after his appointment Ogilvie was sent to inspect Coranderrk. He later recalled that his subsequent report prepared on 20 September 1875 led to superintendent Stähle's dismissal (see below). According to Furphy (2013b: 77) Curr was the key advocate of the plan to close Coranderrk and move its politically active residents to a remote location on the Murray River. Curr believed in Aboriginal infantilism - that they should be under strict control and coerced 'just as we coerce children and lunatics who cannot take care of themselves' (Furphy, 2013b: 77).

Ogilvie reported to the Board that Coranderrk was not a suitable location for an Aboriginal station for two primary reasons: it is too cold and wet for the Aboriginal people to remain in all year round; and it is too near a white population for the Aborigines to be kept clear of the vices - drunkenness and prostitution - incidental to the two races being in such contiguity. He stated that 'although I have no direct evidence of either one or the other taking place to any great extent, it would require a great deal of negative evidence to prove to me that they are not prevalent'. He recommended removing the station to a new location were the white population was less numerous - and he suggested that somewhere on the banks of the Murray River would probably meet both requirements - climate and remoteness. However, Ogilvie considered it was necessary to inform the Board 'that by far the larger proportion of the Aborigines at Coranderrk would prefer remaining there, partly because it is their country, or near it; but probably, also, in a limited degree, for the same reason that the worst part of a white population prefer loafing about towns to going into the country in search of work'.

Ogilvie made some practical suggestions such as 'instead of giving the people their rations once a week, uncooked, it would be better to have a general kitchen, in charge of a white cook, where all their food should be cooked, and from whence it should be issued to them at each meal-time'. The advantages of a central kitchen, he argued, would be food better cooked, less waste, and the people would have the opportunity of keeping their huts in a more cleanly state. If this suggestion was not approved, he recommended the meat ration be issued more often.

Ogilvie offered the Board some remarks about the general management of the Aborigines - he believed they should be divided into classes:

$1^{\text {st }}$ Class - All full-blooded Aborigines, partially or wholly ignorant of the laws of civilization, and all the infirm and aged; all of whom should be managed in a purely paternal manner. 
$2^{\text {nd }}$ Class - All others above a certain age, on being admitted to the station, should be required to sign an agreement with the superintendent to obey all his lawful orders, \&c., and that on any breach of this agreement the superintendent should be authorized to administer such mild punishment as might be thought adequate to the offence (stopping tobacco, \&c.); but that any flagrant breach of discipline they should be summoned before a bench, and treated exactly as a white man would be under similar circumstances, ....

$3^{\text {rd }}$ Class - Which may be called the Educational Class, would of course be composed of the youths of both sexes. I think this class should be so educated that as they arrive at a sufficient age they could be sent into the world to compete for employment with the white population, the station never being closed against them in periods of distress or sickness.

Under some such system as I have sketched, I do not think it would be too much to anticipate, and that at no very remote period that the necessity for a Board might cease; but I do fear that unless the grown-up half-castes are made to feel their personal responsibility to a greater extent than I think they do at present, and unless the young are taught that they will have to battle for their living the same as white people, some future Board for the Protection of Aborigines will have to deal with a vagabond race only distinguishable from the whites in that they will be lower sunk in depravity than the basest of those whites (Victoria, 1876: 6).

Frederick Godfrey, Vice-Chairman of the Board, commented on the suggestion by Ogilvie that the Coranderrk residents be removed to a more genial climate, 'unfortunately, the greater number of the people have a very decided and natural objection to leaving the present station, the Board is of opinion that the wiser course would be to replace about twenty of the worst huts by others more suitable to the climate, and also to form a station at the locality indicated in the report last mentioned, which would not only be useful as a sanitarium for any Coranderrk invalids, but would form the nucleus of a station for the natives of that part of the colony, and which the Church of England Mission has proposed to undertake, with the usual assistance afforded by the Board' (Victoria, 1876: 3).

After the relative stability of Green's leadership, Coranderrk underwent a period of regular leadership change. Ethel Shaw, the daughter of Joseph Shaw who managed the station from 1886 until 1908, explained it as follows:

Troublous times followed during the next few years as five inexperienced and unsuitable men, one after the after, endeavoured to carry out their duties. Not understanding the Aborigines or how to deal with them, they failed to win their confidence and respect. The stronger elements amongst the Aborigines defied authority, refused to work, and were very impudent. One of the managers foolishly threatened the unruly with a gun. A strong young Aborigine knocked him down and took away his gun. Matters became so bad that a Commission was appointed to inquire into conditions. It was realised that the Superintendent must be a Christian, with an understanding, if possible, of the Aborigines (Shaw, 1949:14f).

Johann Henrich Stähle (b. 1840, Germany) who had been appointed teacher in April 1874, served as superintendent for twelve months until he was dismissed on 7 September 1875 for refusing to acknowledge Ogilvie as the Board's Inspector in the place of 
John Green and for what they considered 'improper' correspondence to the Board and his attempt to appeal directly to the Minister. ${ }^{7}$ He was later dismissed and hired by the Anglican Mission Committee to take charge of Lake Condah in October 1875.

On 7 September 1875 Ogilvie was appointed temporary manager of Coranderrk with complete control of the management of the station - his orders from the Board were to enforce 'strict obedience' from the rebellious Coranderrk inmates. On 14 December he was appointed general superintendent of all six stations in Victoria. On 21 September 1875 Ogilvie and Curr were sent 'to search for a new remote location for Coranderrk on the Murray River' (Furphy, 2013: 132).

Miss Nina Robertson, the school mistress and dormitory matron who had been appointed in January 1874, and Thomas Harris, the 45 year old English-born overseer who had been associated with John Green since 1862, were left in charge during Ogilvie's six week absence due to his tour of inspection of the stations across Victoria with Board member E.M. Curr (Barwick, 1998: 99, 116). Massola (1975: 25) however asserts that Robertson was left in charge for five months (he does not mention Harris) and served in this capacity from Stähle's dismissal until her departure from Coranderrk when Ogilvie was appointed, but this chronology is not supported by any other source. In her evidence before the 1877 Royal Commission Robertson asserted that 'For five months I was there alone' (Victoria, 1877: 79) but this may be a reference to her duties as matron and not overall management of the station.

Ogilvie served in a temporary capacity until 42 year old Irish-born sergeant of police Hugh Hamilton Halliday was appointed on 28 March 1876. Ogilvie resigned in mid-1877 to pursue pastoral interests and was succeeded by Captain Page who became Inspector and Secretary. In April 1877 Ogilvie was the first witness examined at the Royal Commission into Coranderrk. He confirmed that he had been engaged in pastoral pursuits in Victoria for some thirty-five years and during this time he had observed the habits and customs of Aboriginal people 'in their natural state'. Ogilvie was asked his opinion of the management of the stations and any improvements he might offer. He replied wishing to draw a distinction between Aborigines on stations and those in the bush - the former have advanced in civilization, and have lost, in a great measure, their original savage modes of life. He thought the centralization of Aboriginal people onto stations was a very good thing because it has had the effect of advancing them in civilization and has enabled the Board to educate the children. Despite these advancements, Ogilvie advised the commissioners 'that just the contrary system should now be introduced. I think the tendency of bringing them on to the stations has been to treat them too much like children, and to destroy any feeling of self-dependence that they ought to have, and I think that they should now be encouraged to labor for themselves, because I imagine the great principle is to

7 According to Barwick (1998: 107), Green recommended Stahle's appointment because he was 'a very good man; the blacks liked him very well'. 
eventually absorb them into the general population of the colony. I think of course that, now we have advanced so far, the sooner that system is commenced the better' (Victoria, 1877: 1)

Halliday resigned in 1878. His replacement was a 59 year old English Church of England clergyman, the Reverend Frederick Philip Strickland who had immigrated to South Australia with his young family in 1855 to take up a new ministry in the Kapunda district. After a five year ministry at Kapunda and Riverton he moved to Geelong in 1861 to become pastor of the Trinity Free Church. He served the Geelong community until 1875. In 1877 he took charge temporarily of a Baptist congregation in Hobart, and in September 1877 returned to Geelong to begin an appointment as Truant Inspector but had to resign owing to a recent ankle injury that restricted his mobility. In June 1882 Strickland was replaced by 36 year old Tasmanian-born William Goodall, a former manager of Framlingham station on the Hopkins River, near Warrnambool. Ethel Shaw writes of Goodall's appointment: 'A Superintendent of a small Aboriginal mission elsewhere took charge for a few years. Admitting that he was unable to cope with the situation or to reduce expenses, which were mounting alarmingly, he resigned, and returned to his former station' (Shaw, 1949: 15). In January 1886 Goodall returned to Framlingham, and 46 year old Yorkshire-born Joseph Shaw (see Figure 1.3), who had been appointed the school teacher at Coranderrk in September 1882, was appointed manager of Coranderrk. Shaw was very experienced - he had served as a missionary for the Church Missionary Society at Yelta on the Murray River near Wentworth (1862-66); at Poonindie Mission Station in South Australia; and had spent some time at Lake Condah mission station in the early 1870 s.

In December 1886, the Victorian Parliament passed the Aborigines Protection Law Amendment Act, which redefined the legal understanding of Aboriginality to be 'full-bloods, half-castes over thirty-five, female half-castes married to Aborigines, the infants of Aborigines' and 'any half-caste who was licensed by the Board to reside on the station'. The purpose of the Act was the removal of Aborigines of mixed descent under the age of 35, who were now legally seen as 'Europeans' and 'non-Aborigines', a move that was designed to reduce expenditure and assimilate them into 'White society'. Aborigines, whose legal identity had changed, were given three years to leave the state's various mission stations and reserves. Ellinghaus's (2001) assessment is that the policy was based on the logic that people of mixed descent were able to look after themselves in mainstream society better than those of full descent because they now had 'white blood'. In implementing the Act the Board actively encouraged genetic assimilation (the eventual 'breeding out' of the Aboriginal population through interracial relationships) and geographic assimilation (forcing Aboriginal people to live among the wider non-Aboriginal community) (Ellinghaus, 2001: 24).

Pursuing what Barwick (1998: 300) refers to as a dispersal policy, the 1886 Act had the following outcomes for Coranderrk: 


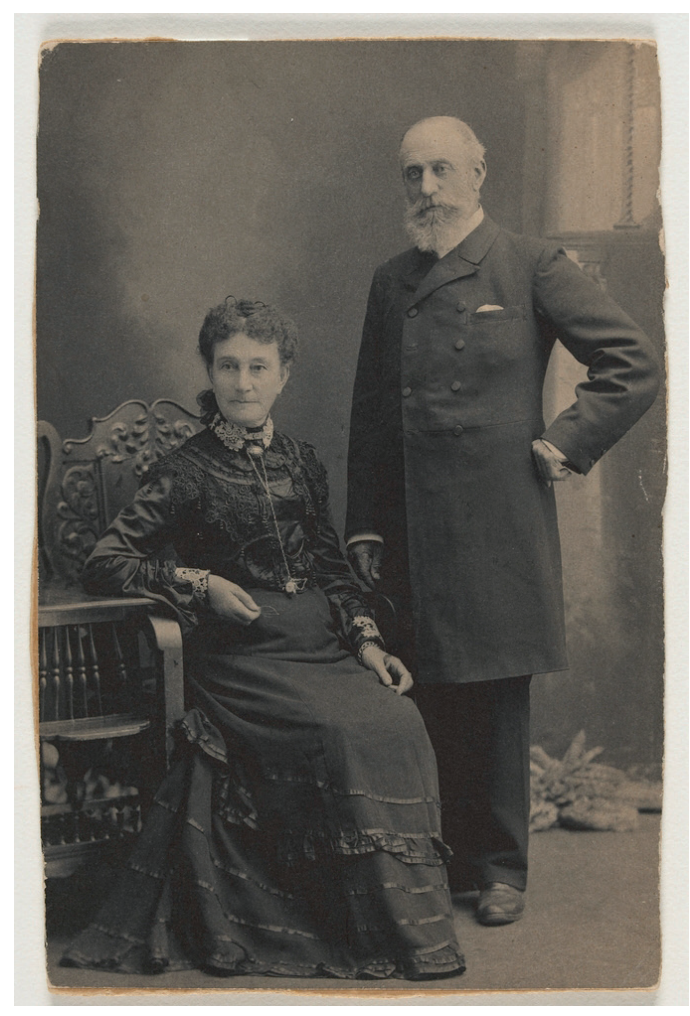

Figure 1.3: Mr and Mrs Joseph Shaw, Coranderrk 1902, State Library of Victoria Pictures Collection Accession No. H17940.

All 'half-castes' born after 1852 (i.e. 13 years and over) were ordered to find work and homes for themselves off the stations and the children of those 'over-age' 'half castes' still eligible to live on the stations were sent out as domestic servants and farm labourers from the age of 13 . The sick and needy could be licensed to receive temporary refuge at the stations; but the government's new insistence on retrenchment, as the economic recession developed into the severe depression of the 1890s, limited aid to only the most desperate cases.

A majority of the 50 'half castes' at Coranderrk who were exiled by the passage of the 1886 Act, eventually took refuge in New South Wales at or near Maloga mission near Moama, and the newly-formed Cummeragunja station near Barmah.

In 1889 the Healesville Shire Council lobbied the Board for the Protection of Aborigines to alienate land from the Coranderrk station to allow for a model dairy farm and to cut an access road through the reserve. Despite the Coranderrk residents petitioning against the interests of the Healesville Shire, in 1891 the Board approved the road (which had been constructed illegally in the interim), and gave the shire a lease of the land required for an agricultural college. The road effectively cut the 
station into two halves, and in 1893 the Board relinquished the eastern half nearest Healesville for village settlement. Once again the Aboriginal residents at Coranderrk protested the reduction of their station. By 1893, some 50 former residents were reported by Shaw to be 'earning, or at least obtaining, a living elsewhere'.

In 1903, Shaw was given six month's leave of absence; in his absence his 29 year old daughter Ethel Shaw served as matron, and 70 year old Scottish born John Mackie, the former school teacher, came out of retirement to serve as Acting Manager. Shaw retired in June 1908, and pending a permanent appointment, the station was put in the hands of John Mackie and 30 year old Frank T. Bulmer, the son of John Bulmer, the manager of Lake Tyers station. They remained in that role until January 1909 when 42 year old Avoca-born Charles Robarts (see Figure 1.4) was appointed superintendent and Natalie Robarts, matron (see Figure 1.5). The Robarts remained in charge until the closure of Coranderrk in 1924.

In 1909, newly-appointed Robarts confirmed that he maintained the Board's rule that the 'outside half-castes are restricted to one day a week to visit their relatives and friends'. These included descendants of pioneer Coranderrk families - Davis, Franklin, Harris, Hunter, Manton, Patterson, Rowan, Russell, Terrick, and Wandin - who camped in huts and tents to be near their 'old people' at Coranderrk.

In 1910, the 1886 Act was amended so that previously excluded Aborigines of mixed descent could receive aid through Aboriginal stations and missions. In 1912 some 66 Aboriginal residents were living at Coranderrk. In 1914 and 1915 Healesville residents petitioned the government to resume the reserve for a permanent military camp. The Healesville Shire Council organized a public protest meeting asserting that 'the congregation of a degenerate race a few miles from the township will ruin Healesville as a tourist resort' (Barwick, 1998: 306-7). This was a ridiculous claim given that Coranderrk was a staple for the tourism industry and as is shown throughout Natalie Robarts's diary, many international visitors to Melbourne included a trip to Coranderrk as a mandatory part of their visit. Barwick (1998: 307) asserts that in the post war years some 2,000 visitors went to Coranderrk per annum.

Given the economic pressures stemming from the 1890s depression, and pressure exerted from land-hungry neighbours, the Board was pressed to reduce costs by amalgamating stations and/or reducing the size of station land. Framlingham closed in 1890; Ebenezer in 1904, Ramahyuck in 1909, and Lake Condah in 1918, and many of their residents were forcibly resettled at Coranderrk.

In 1917 the Board decided to 'concentrate' all eligible Aboriginal people at Lake Tyers. Any eligible Aboriginal station residents who refused to leave their homes would be deemed to have foregone any future assistance. In 1918 when the Board planned to close Coranderrk and concentrate Aboriginal people at Lake Tyers, some 33 residents were willing to resettle, and 24 refused. Coranderrk was eventually 'closed' in February 1924 when the manager Charles Robarts was removed. The Board resolved that Annie and Lanky Manton, Mrs Dunolly, Alfred Davis and his wife, and William Russell were allowed the use of 50 acres [20 hectares]. 


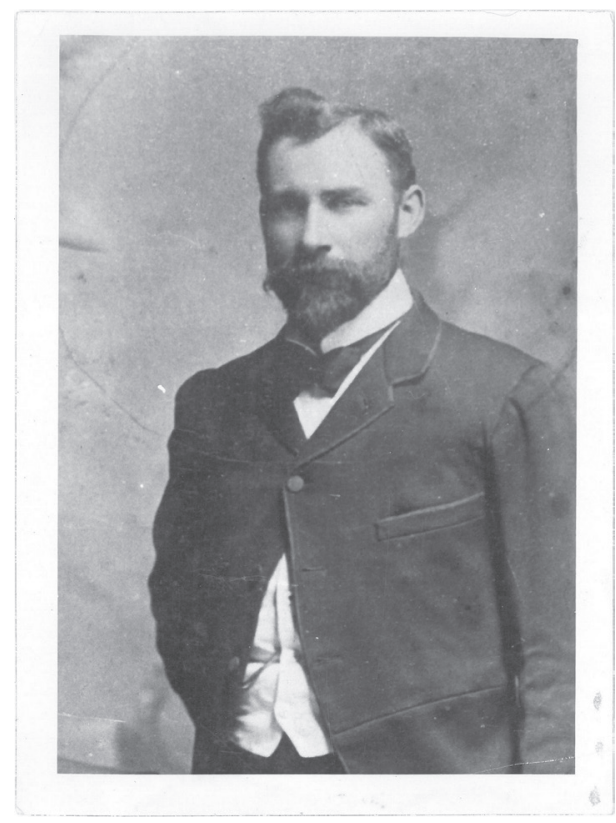

Figure 1.4: Charles Alfred Robarts (Source: the Natalie Robarts papers).

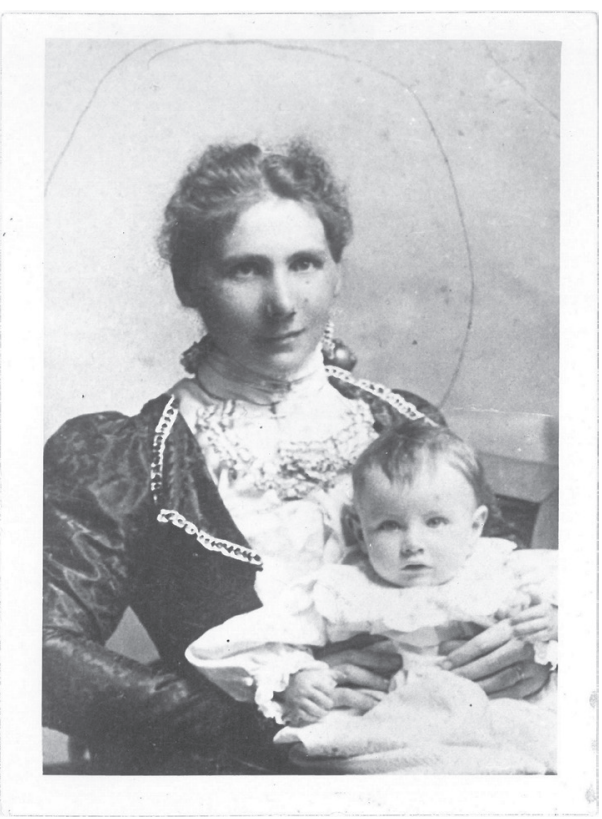

Figure 1.5: Natalie Anna Robarts, 1901 (Source: the Natalie Robarts papers). Presumably the baby she is holding is her first-born son, Oswald Charles Robarts. 


\subsection{About This Book}

Chapter two is concerned to provide a chronological overview of tourism at Coranderrk from 1863 until its closure in 1924. Chapter three considers contributions from six researchers - E.H. Giglioli, H.N. Moseley, C.J.D. Charnay, Rev. J. Mathew, L.W.G. Büchner, and Professor F.R. von Luschan. It translates and publishes Giglioli's and Charnay's accounts of their visits to Coranderrk. Chapter four considers 14 international dignitaries, including royal visitors and members of the political elite - visitors as diverse as media baron Lord Northcliffe and acclaimed English historian James Froude. Chapter five is concerned to analyse seventeen published accounts from journalists and correspondents who visited Coranderrk. They reveal the development of the station and show the evolution of Coranderrk as a tourist attraction and the response of the Aboriginal residents to this growing interest. A particular study is made of the articles of John Stanley James aka The Vagabond. Chapter six is concerned with the tourism that emerged around the eminent ngurungaeta (clan head) William Barak - it translates and publishes Comettant's and Baessler's accounts of their meetings with Barak. Chapter seven analyses commercial photography and postcards of Coranderrk that were generated during its operation, along with examples of private photographs taken by tourists. Chapter eight briefly explores tourism at Coranderrk after its closure in 1924. Finally, chapter eight's appendix presents biographical histories of each superintendent and acting manager; and reveals what I have been able to learn about their backgrounds and their lives before and after Coranderrk, and their immediate families. One of the purposes of these portraits is to correct some of the ignorance and misinformation surrounding some of these men and women.

\section{Select References}

Attwood, B. (1987). Tara Bobby, A Brataualung Man. Aboriginal History. 11. 41-57.

Attwood, B. (1989). The Making of the Aborigines. St Leonards: Allen and Unwin.

Barwick, D.E. (1998). Rebellion at Coranderrk. Canberra: Aboriginal History Inc.

Billis, R.V. and A.S. Kenyon (1974). Pastoral Pioneers of Port Phillip. Melbourne: Stockland Press.

Byrne, D. (1996). Deep nation: Australia's acquisition of an indigenous past. Aboriginal History. 20: 82-107.

Cannon, M. (Ed.). (1969). The Vagabond Papers. Melbourne: Melbourne University Press.

Carolane, P. (2008). 'Parallel Fantasies: Tourism and Aboriginal Mission at Lake Tyers in the Late Nineteenth Century' in A. Barry, J. Cruickshank, A. Brown-May, \& P. Grimshaw (Eds.) Evangelists of Empire?: Missionaries in Colonial History (160-172). Melbourne: University of Melbourne eScholarship Research Centre.

Cato, N. (1976). Mister Maloga: Daniel Matthews and his Mission, Murray River, 1864-1902. Brisbane: University of Queensland Press.

Clark, I.D. (1982). The Ethnocide of the Tjapwurong - the Nexus between Conquest and Non-Being. Unpublished BA. Hons. Dissertation. Clayton: Department of Geography, Monash University. 
Clark, I.D. (2014). The Last Matron of Coranderrk: Natalie Robarts's Diary of the Final Years of Coranderrk Aboriginal Station, 1909-1924. Charleston: Createspace Independent Publishing.

Clark, I.D. \& McRae-Williams, E. (2014). Tourist Visitation to Ebenezer Aboriginal Mission Station, Victoria, Australia, 1859-1904: a case study. Tourism, Culture \& Communication. 13(2): 113-123.

Clowes, E.M. (1911). On the Wallaby Through Victoria. London: William Heinemann.

De Lorenzo, C. (2006). Review. Visual Resources: An International Journal of Documentation. 22(3): 290-297.

Denzin, N.K. (1989). Interpretive interactionism. Newbury Park, CA: Sage.

Donnelly, K. (2011). Eye Contact: Photographing Indigenous Australians [Book Review]. History Australia. 4(2): 65.1.

Edwards, E. (2006). Eye Contact: Photographing Indigenous Australians [Book Review]. Australian and New Zealand Journal of Art. 7(2): 77-80.

Ellinghaus, K. (2001). Regulating Koori marriages: the 1886 Victorian Aborigines protection act. Journal of Australian Studies. 25(67): 22-29.

Fels, M.H. (2011). 'I succeeded once’ The Aboriginal Protectorate on the Mornington Peninsula, 1839-1840. Aboriginal History Monograph 22. Canberra: ANU E Press.

Furphy. S. ( 2013a). Edward M. Curr and the Tide of History. Canberra: Australian National University Epress \& Aboriginal History Inc.

Furphy, S. (2013b). The Trial of Warri: Aboriginal protection and settler self government in colonial Victoria. Journal of Australian Colonial History. 15: 63-82.

Goodall, H. (1996). Land in our own country: the Aboriginal land rights movement in southeastern Australia, 1860-1914. In V. Chapman \& P. Read (Eds.), Terrible Hard Biscuits: A reader in Aboriginal History (167-201). Canberra: Aboriginal History.

Gott, B. (2010). Aboriginal Plants in the grounds of Monash University - A Guide. Clayton: School of Biological Sciences, Monash University.

Gunson, N. (2007). Eye Contact: Photographing Indigenous Australians [Book Review]. Aboriginal History. 31: 195-199.

Hall, C.M. and Tucker, H. (2004). 'Tourism and postcolonialism an introduction' in C.M. Hall \& H. Tucker (eds) Tourism and Postcolonialism: contested discourses, identities and representations (1-24). London: Routledge.

Healy, S. (2006). 'Years Ago Some Lived Here' Aboriginal Australians and the Production of Popular Culture, History and Identity in 1930s Victoria. Australian Historical Studies. 128: 18-34.

Jeffery, D. (2006). Eye Contact: Photographing Indigenous Australians [Book Review]. Australian Aboriginal Studies. 2: 128-130.

Jensz, F. (2010). German Moravian Missionaries in the British Colony of Victoria, Australia, 1848-1908: influential strangers. Leidon: Brill.

Kleinert, S. (2012). 'Keeping up the Culture’: Gunai Engagements with Tourism. Oceania. 82: 86-103.

Kratz, C.A. (2008). Eye Contact: Photographing Indigenous Australians [Book Review]. American Ethnologist. 35(3): 3042-3046.

Lydon, J. (2002). The experimental 1860s: Charles Walter's images of Coranderrk Aboriginal Station, Victoria. Aboriginal History. 26: 78-130.

Lydon, J. (2005). Eye Contact Photographing Indigenous Australians. Durham: Duke University Press.

MacDonald, C. (1963). Memories of Coranderrk Aboriginal Mission. Victorian Historical Magazine. 35(137): 102-135.

Markus, A. (1977). Through a Glass, Darkly: Aspects of Contact History. Aboriginal History. 1(2): 170-180.

Massola, A. (1975). Coranderrk A History of the Aboriginal Station. Kilmore: Lowden Publishing. Nanni, G. (2011) Time, empire and resistance in settler-colonial Victoria. Time Society. 20 (1): 5-33. 
Nanni, G. \& James, A. (2013). Coranderrk: We Will Show the Country. Canberra: Aboriginal Studies Press.

Otter, R.H. (1882). Winters Abroad. Some information respecting places visited by the author on account of his health... London: John Murray.

Peck, J. (2010). Performing Aboriginality: Desiring Pre-contact Aboriginality in Victoria, 1886-1901. History of Photography, 34(3): 214-233.

Ponteretto, J.G. (2006). Brief Notes on the Origins, Evolution, and Meaning of the Qualitative Research Concept “Thick Description”. The Qualitative Report. 11(3): 538-549.

Ryland, W.P. (1886). My Diary During a Foreign Tour in Egypt, India, Ceylon, Australia, New Zealand, Tasmania, Fiji, China, Japan, and North America, in 1881-2. Birmingham: The Author.

Shaw, E. (1949). Early days among the Aborigines: the story of Yelta and Coranderrk Missions. Fitzroy: The Author.

Sinnott, N. (2003). Place-Names of the Alexandra, Lake Eildon and Big River Area of Victoria. Alexandra: Friends of the Alexandra Library.

Stephens, M. (Ed.) (2014). The journal of William Thomas: assistant protector of the Aborigines of Port Phillip \& guardian of the Aborigines of Victoria 1839 to 1867. (4 Vols.) Melbourne: Victorian Aboriginal Corporation for Languages.

Sturrock, N. (2005). Bishop of Magnetic Power James Moorhouse in Melbourne, 1876-1886. Melbourne: Australian Scholarly Publishing.

Tester, R. (No Date). Wombat Wallaby or Reminiscences of a Trip Overland to Melbourne and the Gold Fields, Unpublished Manuscript, Mitchell Library, State Library of New South Wales, Sydney, ML B1652.

Trollope, A. (1967). Australia. Edited by P.D. Edwards and R.B. Joyce. Brisbane: University of Queensland Press.

van Toorn, P. (2006). 'Hegemony or Hidden Transcripts?: Aboriginal Writings from Lake Condah, 1876-1907' Journal of Australian Studies. 86: 15-27, 177.

Verschuur, G. (1891). At the Antipodes Travels in Australia, New Zealand, Fiji Islands, The New Hebrides, New Caledonia, and South America 1888-1889. London: Sampson Low, Marston \& Company.

Victoria. (1861). First Report of the Central Board Appointed to Watch Over the Interests of the Aborigines in the Colony of Victoria. Melbourne: John Ferres, Government Printer.

Victoria. (1871). Seventh Report of the Board for the Protection of the Aborigines in the Colony of Victoria. Melbourne: John Ferres, Government Printer.

Victoria. (1876). Twelfth Report of the Board for the Protection of the Aborigines in the Colony of Victoria. Melbourne: George Skinner, Acting Government Printer.

Victoria (1877). Royal Commission on the Aborigines. Report together with Minutes of Evidence and Appendices. Melbourne: John Ferres, Government Printer.

Victoria. (1904). Fortieth Report of the Board for the Protection of the Aborigines. Melbourne: Robert S. Bain, Government Printer.

Westmeier, K. W. (1997). Becoming all Things to all People: Early Moravian Missions to Native North America. International Bulletin of Missionary Research. 21(4): 172. 